\title{
Bio-geo-graphy: landscape, dwelling and the political ecology of human-elephant relations
}

\section{Maan Barua}

\begin{abstract}
The relation between the bio and the geo has been amongst geography's most enduring concerns. This paper contributes to ongoing attempts in human geography to politicize the dynamics and distribution of life. Drawing upon postcolonial environmental history, animal ecology and more-than-human geography, the paper examines how humans and elephants cohabit with and against the grain of cartographic design. Through fieldwork in northeast India, it develops a 'dwelt political ecology' that reanimates landscape as a dwelt achievement whilst remaining sensitive to postcolonial histories and subaltern concerns. The paper conceptualizes and deploys a methodology of 'tracking' through which archival material, elephant ecology and voices of the marginalized can be integrated and mapped. It concludes by discussing the implications of this work for fostering new conversations between more-than-human geography and subaltern political ecology.
\end{abstract}

Keywords = more-than-human geography, political ecology, Asian elephant, landscape, subaltern studies, biogeography, cultural geography, postcolonial

\section{Introduction}

This paper begins by tracking. It is a dark September night in Sonitpur, a district in rural northeast India. I am with a team of conservation researchers on the trail of an elephant herd. Villagers have reported that the animals ventured out of a forest reserve to raid rice paddy. We enter a seamless, black field hoping to spot the animals. Only the sounds of our moving feet punctuate the silence, sinking into the soft earth, rising up again. Searchlights echo in the far distance. The elephants have been spotted. My companions suggest we wait, for the animals may come our way. Three quarters of an hour later, we hear that sound familiar to those who inhabit the world with elephants. The uprooting of paddy, stalks shaken to remove clinging earth, soft rumbles. The sounds then dim. We lose the elephants to the night. The next morning, traces of elephant presence are everywhere. Tracks of a herd of four on the soil, trampled rice paddy, bricks scattered from a demolished wall. The tea plantation workers to whom the house belonged are angry and desperate: "We constantly face this problem. These animals belong to the government, but we have to live with them. As for compensation, it never reaches us. Neither can we move out of here. With so many mouths to feed, you tell us what to do."

This vignette gives us a sense of the politics that emerges when more-thanhuman bodies (bio) and a lively earth (geo) interweave. As in many parts of the world, landscapes of human-animal cohabitation are politically fissured into reserves for elephants and spaces for people. Yet, elephants transgress these cartographic divisions, where they come into conflict with the rural poor. The latter bear an unequal burden of living with elephants, creatures afforded protection and deployed 
by the state to control vast tracts of land. This interplay between human and elephant bodies, landscapes and institutions, weaves an ecology that is inherently political, but a mode of politics that exceeds human deliberation. At work here is an earth-life nexus shaping disputed presents in the shadow of a colonial past.

But how should we make sense of such lively, political, modes of cohabitation? How might we write (post)colonial histories in a way that does not render inert the actions and agencies of nonhuman animals? What bearings does it have for understanding the vital connections between the bio and the geo - one of geography's most enduring concerns (Whatmore, 2006)? These questions have been the staple of political ecology and environmental history. Political ecology has sought to unpack how human-animal cohabitation is mediated by broader political struggles such as that of race, gender and class (Ogra, 2008; Robbins, 2011), it has examined how political economies of power and capital control landscapes (Peluso, 1995; Zimmerer and Bassett, 2003), and it has tended to the politics of environmental change and degradation that result when resources are integrated into regional and global markets (Robbins, 2001). South Asian environmental history, inspired by subaltern perspectives of writing history 'from below' (Chakrabarty, 2002; Guha, 1982), have challenged mainstream environmental narratives to elucidate how political protests ensue following the creation of protected areas (Arnold and Guha, 1995; Guha, 1990; Rangarajan, 1996a). Whilst important for understanding how ecology is politicized, these approaches tell us very little about the nonhumans with whom humans cohabit, and the part they play in coproducing landscapes. As critics often ask, where is the ecology in political ecology (Walker, 2005)?

In response, more-than-human geography has approached these questions by seeking to re-materialize and re-animate landscapes. ${ }^{1}$ They pay close attention to the ecologies of human and nonhuman bodies through which a vital topography emerges (Johnston, 2008; Lorimer, 2006, 2010a). The emphasis here is on landscapes as dwelt achievements of people and animals rather than surfaces upon which human meanings are inscribed (Hinchliffe, 2003). This concern with dwelling is shared by the environmental anthropology of Tim Ingold, who argues that the diverse ways human and nonhuman animals perceive and inhabit their shared environments contributes to a landscape's continual regeneration (Ingold, 2000, 2011). In a slightly different register, and at much broader scales, others have sought to examine the dynamics and distribution of life 'after the end of Nature' (Lorimer, 2012). Such perspectives seek to develop 'lively' or 'intra-disciplinary' biogeographies, drawing the natural and social sciences into conversation (Jepson et al., 2010; Lorimer, 2010b). This intra-disciplinary

\footnotetext{
${ }^{1}$ Scholarship within political ecology that brings in ecology include studies that attend to socio-ecological transformations of landscapes Robbins P, 2001, "Tracking Invasive Land Covers in India, or Why Our Landscapes Have Never Been Modern" Annals of the Association of American Geographers 91 637-659, examine spatial and temporal variability of a landscape's biophysical conditions Fairhead J, Leach M, 1996 Misreading the African landscape: society and ecology in a forest-savanna mosaic (Cambridge University Press, Cambridge), and account for the ecological variables shaping a landscape's formation Zimmerer K S, 1999, "Overlapping Patchworks of Mountain Agriculture in Peru and Bolivia: Toward a Regional-Global Landscape Model" Human Ecology 27 135-165. This body of work, however, edges towards a politics of representation rather than the materiality of landscapes (for a critical review see: Neumann R P, 2011, "Political ecology III: Theorizing landscape" Progress in Human Geography 35 843-850)
} 
endeavour also calls for incorporating ethology into ethnographic practice (Lestel et al., 2006). A field of study concerned with animal behaviour, ethology has made its way into more-than-human geography through readings of Deleuze and von Uexküll, among others (Lorimer, 2010a). Whilst bringing back the life that is rendered inert by political ecology, conversation between more-than-human geography and political ecology are still nascent. We learn very little about the lived experiences of inhabitation, of humans or animals, or about landscapes, in the shadow of the (post)colonial state.

Both perspectives have much to offer in terms of investigating how humans and animals inhabit a lively earth, with and against the grain of political design. In this paper, I seek to develop a 'dwelt political ecology' that is attuned to how more-thanhuman bodies fabricate landscapes whilst collectively caught up within fields of power. The paper draws postcolonial environmental history (Arnold and Guha, 1995; Gadgil and Guha, 1992), and political ecology (Robbins, 2011), into conversation with more-than-human geography (Whatmore, 2002, 2006), and scholarship on animating landscapes (Ingold, 2000, 2011). Crafting such political ecologies that do not deaden nonhumans or the landscape demands methodological innovation. Deploying a subaltern reading of archival material, the paper first examines how human-elephant relationships unfolded in a colonial and postcolonial landscape in northeast India. Second, the paper interrogates what this archival reading of human-elephant landscapes would mean if one were to consider the ecologies and lifeworlds of elephants. This is mobilized through a five-month endeavour of tracking a herd of bull elephants in the same landscape. Finally, the paper engages with the politics of cohabitation by tracing the stories of postcolonial subalterns who interacted with the bull herd. Through these interventions, the paper offers up innovative methods for writing (post)colonial political ecologies. It contributes to wider literatures looking at the earth-life nexus in human geography.

\section{Bio-geo-graphy I: Political ecology from the archive}

I first travelled to Sonitpur in the late summer of 2010 to understand how elephant conservation unfolded on the ground. One of my early encounters was that of an official map (Figure 1), delineating elephant distribution in the region. The contrast between the elephant reserves under the aegis of the forest department and blank spaces meant to depict human habitation was stark. This apparently peaceful settlement of reserves for elephants and spaces for humans posed a number of questions. Under what political economic circumstances did these institutional arrangements of people and elephants arise? Were concerns of the subaltern citizen mapped out by this cartography? How did these cartographic practices regulate the activities of people and elephants? 


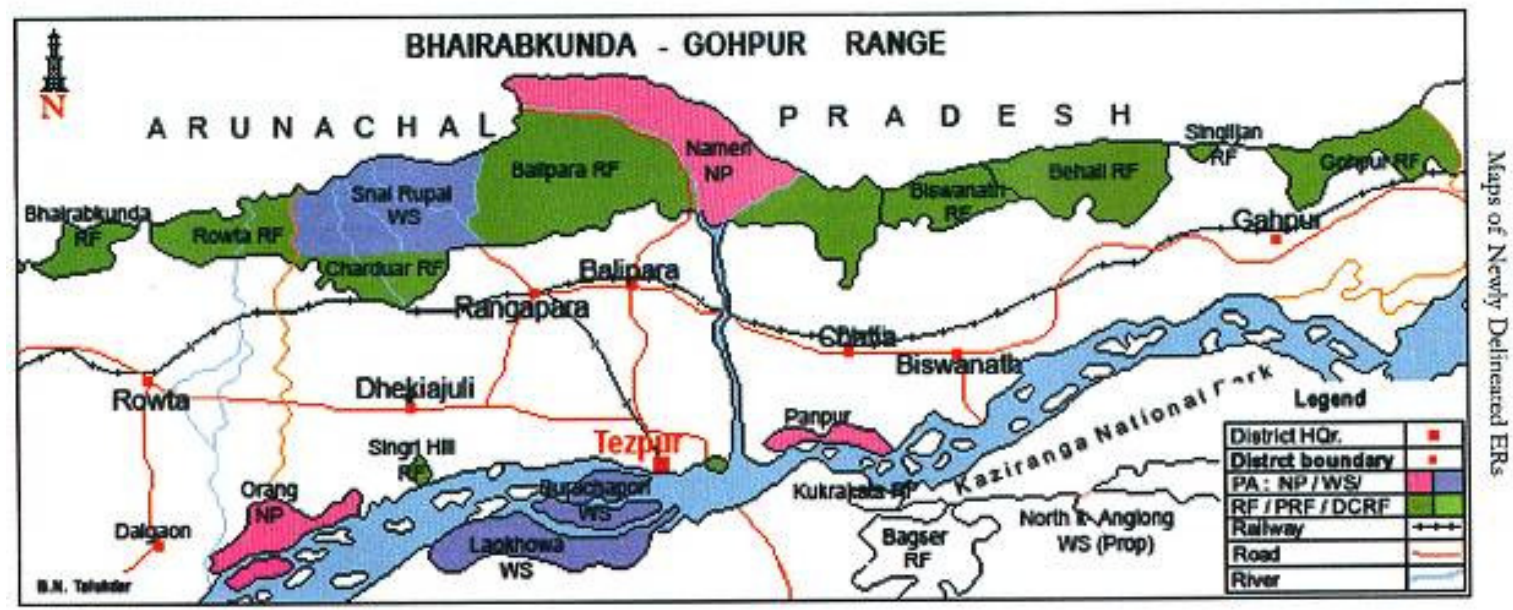

Figure 1: Institutional cartography of the Sonitpur Elephant Reserve. Shaded areas in green, pink and dark blue indicate formally designated protected areas; white indicates human settlement. Source: Government of Assam (2010).

Such questions are a familiar trope in political ecology, but they foreground the histories through which divisions between nature and society were entrenched and coded into the landscape. This Modernist cartographic practice (Latour, 1993; Robbins, 2001), had its roots in colonial forestry. The Sonitpur Elephant Reserve depicted on the map was assembled from erstwhile protected areas created for forestry operations in the 19th century (Talukdar, 2010). Archival material indicates that following the annexation of Assam in 1838-39, the East India Company began a series of moves to fence forests from the local populace. Cartographic surveys of the landscape were initiated in the 1840 s with the motive of identifying trees with commercial value (Saikia, 2005). Until the 1860s, the imperial administration allowed mauzadars $^{2}$ from the local populace to fell trees in return for a nominal tax. Thereafter, following the rise of systematic forestry across the Indian empire that developed new ways to plant, order and produce timber through rational methods of regeneration (Agrawal, 2005; Arnold and Guha, 1995; Gadgil and Guha, 1992), such practice was rendered 'reckless' and a 'cause of concern' by the imperial government (Handique, 2004). In 1873, areas containing valuable forest produce were demarcated and declared reserve forests (Figure 2), following the logic of fencing 'strictly what we could find really merchantable timber growth' whilst leaving 'the rest to the uses of the local population' (Saikia, 2005, p.56). New geographies of resource use were forged through regulations limiting access to forests, resulting in e colonial ownership of a large proportion of land within the district.

Such fencing of forests witnessed a parallel commodification of the elephant. Like timber, elephants were considered 'produce' of state-owned forests to which the colonial government gained privileged access. By the mid-1870s, elephant capture and trade, in operation since pre-colonial times (M'Cosh, 1837), and run by feudal estates and private contractors (Campbell, 1869), was increasingly regulated by the imperial

\footnotetext{
${ }^{2}$ A private revenue agent or "revenue farmer" who represents an allocated region and collects revenue on behalf of the government with certain personal profit
} 
government. Forest reserves in Sonitpur were partitioned into sections and given out on lease to the highest bidder (Hunter, 1879). Royalty had to be paid for every animal caught and the government reserved the right to purchase all elephants from the lessee. Initial regulation soon gave way to complete state monopoly and ownership of the animal. The 'Elephants' Preservation Act' was constituted in 1879, prohibiting any capture or killing of elephants, unless granted a license. The state therefore exercised ownership of elephants irrespective of whether they were in forest reserves or outside (Nongbri, 2003). The legitimacy to govern elephant populations and the authority to dictate modes of human-elephant cohabitation now rested with the colonial government.

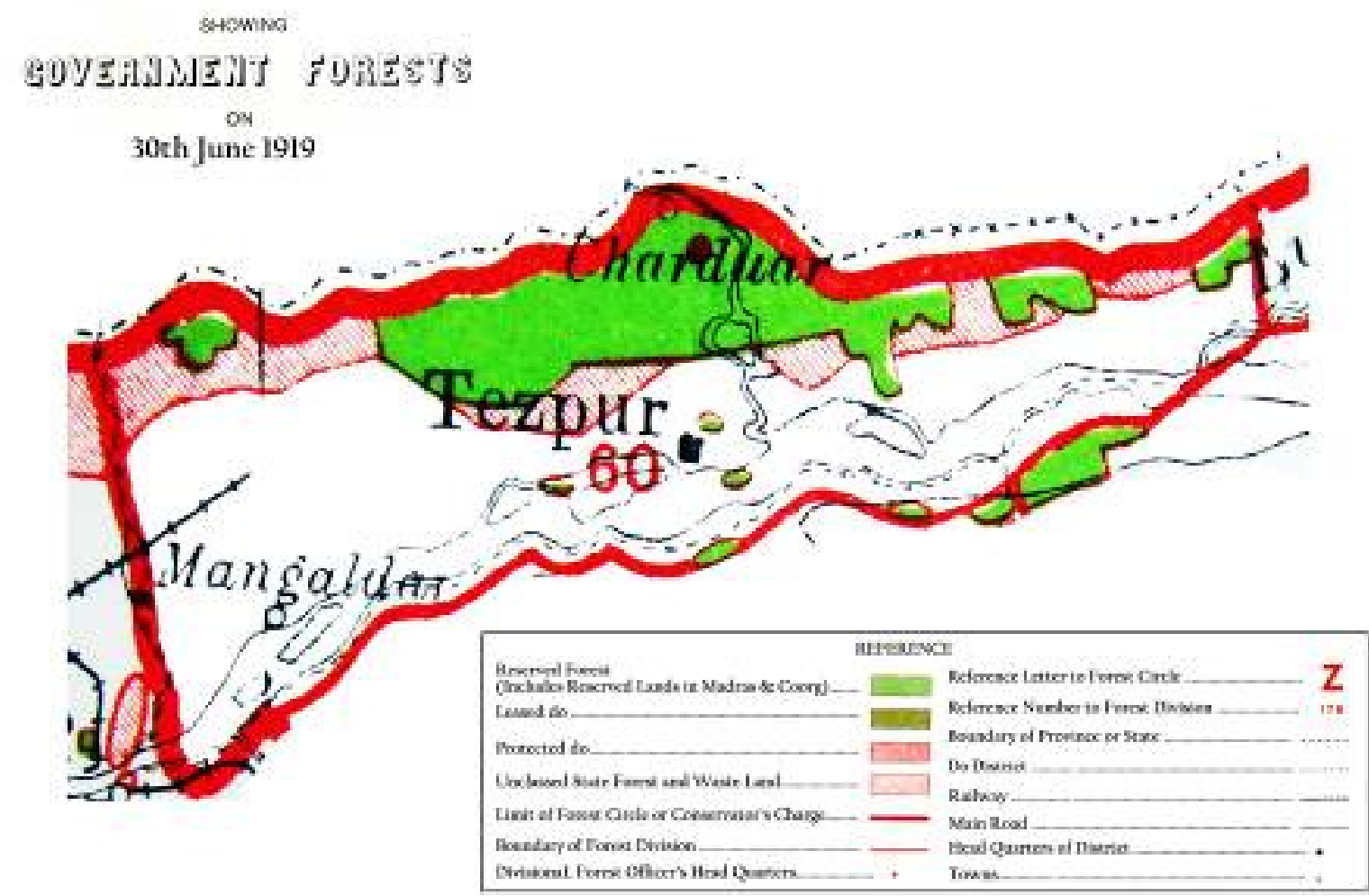

Figure 2: Map showing areas demarcated for commercial forestry in Sonitpur (Darrang), 1919. Areas in green show newly constituted reserve forests; those shaded in red indicate 'Unclassed state forests'. Source: Bodleian Library, Oxford.

Two schisms arose from this simultaneous fencing of forests and commodification of elephants. First, there was a disentanglement of nature from society, resulting in a purification of the landscape (Latour, 1993). Second, there was an inversion of inhabitation into occupation (Ingold, 2011), whereby the landscape became a constructed space with forests occupied by commodities like the elephant and 'the rest' by the local populace. These schisms were not produced without protest and conflict. Fragmentary deposits in archives seldom contain voices of the marginalized, but records suggest that there was considerable tension between 
agricultural expansion and advocates of forest preservation. The local peasantry constantly insisted on grazing and cultivation rights, whilst the more powerful tea industry made demands for 'de-reservation' of forest areas to increase plantations (Saikia, 2008). In response, besides stating that the 'forests of Assam are not inexhaustible' (Progress Report of Forest Administration 1926-27 cited in Handique, 2004, p.10), the forest department retained their grasp over land on the grounds that they contained populations of elephants that could be captured for further use (Nongbri, 2003). Further, the 'question of game preservation in Assam' was invoked. The forest department, deploying a hegemonic logic (Gramsci, 1971) to maintain control over land, argued that ' $[\mathrm{t}]$ he public ... needs educating upto the fact that wild animals and the study of their habits are sources of great interest and delight to men of real culture throughout the civilized world' (Progress Report of Forest Administration 1929-30 cited in Handique, 2004, p.86). (Gramsci, 1971) Amidst much protest, in the 1940s the Assam Legislative Assembly adopted a bill empowering the forest department to evict anyone occupying forest land (Saikia, 2005). The processes of purification and inversion, initiated by the fencing of forests, were made complete through this power to evict.

However, archival readings show how the histories through which purification proceeded were also replete with translations - hybrids of nature and culture, mixtures between new types of being that resist modernist binaries (Latour, 1993). Unlike the distinct ontological zones of purification, translations are rhizomatic, their topology not about spatial order but a spatiality of performed relations between ontologically heterogeneous beings (Law, 1999). ${ }^{3}$ Purification of the Sonitpur landscape and commodification of elephants generated a view that elephants, being state-owned animals, should remain in forests reserved for them. Yet, the forest department continually received complaints about elephant incursions and crop damage from the local populace (Anon., 1957, p.28). The issue even reached the Assam Assembly, where a speaker contended that 100,00o acres of land, with a crop output equivalent to $1.25 \%$ of India's food deficit, could not be cultivated due to intruding elephants (Gee, 1950). Efforts to control elephant depredation in Sonitpur through Kheddah and Mela Shikar capture operations, did little to solve the problem. Most damage was apparently 'the work of solitary male elephants' for which such operations were 'of no avail' (Paramasivan, 1961, p.29). Realizing that opening up all reserves for elephant capture was 'no answer to the problem' (Anon., 1957), licences were issued to 'approved and experienced sportsmen' to shoot 'rogues'. Due to a paucity of skilled hunters, even armed police were sent to 'destroy' elephants, but it(Paramasivan, 1961) 'merely result[ed] in reckless shooting and the killing and wounding of all and sundry, including females and calves' (Paramasivan, 1961, p.31). Despite serious effort, elephant depredation remained a problem that was difficult to manage and govern.

In the decades after Indian independence, leading to the designation of the Sonitpur Elephant Reserve in 2003 (Bist, 2006), the postcolonial government did little

\footnotetext{
${ }^{3}$ The intertwining and knotting of nature and society through translations is essential for practices of purification, for without the former, the latter would be pointless. Purification thus thrives on translations, but the Modern stance is to keep these two simultaneous practices separate Latour B, 1993 We have never been modern. (Harvard University Press, Cambridge, MA).
} 
to alter these Modernist cartographies of governance. Rather, in the 1970s, a policy of 'total preservation' emerged. Rooted in the idea that India as an emerging nation should preserve its 'cultural and biological identity' through the retention of 'representative patches' of forests (Rangarajan, 1996b), all modes of human activity was to be erased from protected areas. Whenever tolerated, human presence was deemed a necessary evil. (Lahiri-Choudhury, 1989)A drive toward protection through bureaucratic intervention ensued, leading to the passing of The Wildlife (Protection) Act in 1972. The elephant, viewed by elites to be integral to India's cultural and biological identity (Lahiri-Choudhury, 1989), was elevated to Schedule I of this act in 1977. The creature could now only be killed if it had become 'dangerous to human life' or 'sick beyond recovery', not for destroying crops or property (Lahiri-Choudhury, 2006). Translations such as conflict and crop depredation were no longer issues to be managed through hunting and population control. They were to be tolerated, or in the worst scenario, mitigated through bureaucratic measures such as compensation.

In summary, this archival reading of human-elephant relationships opens up articulations of the nexus between the bio and the geo to fraught political pasts. This brief history of the Sonitpur landscape, written to understand subaltern concerns, demonstrates how contemporary modes of elephant conservation are rooted in a colonial political economic context of maximizing revenue from forests (Arnold and Guha, 1995). The cartographies that it heralded were Modernist, entrenching divisions between nature and society, and inverting inhabitation into occupation (Ingold, 2011; Latour, 1993). The same practices gave the state authority to govern landscapes and dictate how people and elephants should inhabit them, an authority that was further strengthened through bureaucratic control in postcolonial India. Archival records, despite their poor repository of the voices of the marginalized, suggest that concerns of the peasantry were seldom heard. Translations,, in the form of elephant incursions into human habitation, were highly uneven encounters - elephants benefited from state protection and the rural poor could do little but tolerate their presence.

\section{Bio-geo-graphy II: Tracking elephants}

Documents and maps that find their way into archives are elements of a landscape's past. They help articulate the politics through which human-elephants relations unfold. Archives comes alive when documents start to unravel translations, the moments when elephants refuse to be contained within perimeters and go against the grain of cartographies that authorities set them. Yet, a sense of unease permeates when writing such translations, for the lively beings that bring them about are qualitatively absent. We learn little about elephants' lifeworlds, or what the landscape might mean for them. But what if we began to articulate this politics with a slightly different awareness of elephants and their relations with the landscape? An awareness that begins through an involvement in the activities of elephants that contributes to the landscape's ongoing regeneration? How would we mobilize such an awareness, and what would be at stake for subaltern ecological histories?

Moving back to the field from the archives, I followed a herd of elephants over the course of five months, between September 2010 and January 2011, as they traversed the Sonitpur landscape. I was shadowing the work of three researchers - Dhruba, Bhaben and Apu - who worked for the Assam Haathi Project (AHP), a humanelephant conflict mitigation project funded by the UK DEFRA Darwin Initiative. The 
team was monitoring the activities of a herd of four bull elephants, named SPo4, an activity they referred to as 'tracking'. Led by Tara-1, the dominant mukhna ${ }^{4}, \mathrm{SPo} 4$ had become experts at raiding crops and breaking into houses for stored food grain. The three other elephants in the herd included Tara-3, a subadult male about 10 years old, and two older animals Tara-4 and Tara-5 (Figure 3). A fifth elephant, Tara-2, had left the herd before I had commenced fieldwork. The prefix Tara- attached to their names stemmed from Tarajuli, the place where the AHP team first identified the herd in 2006.

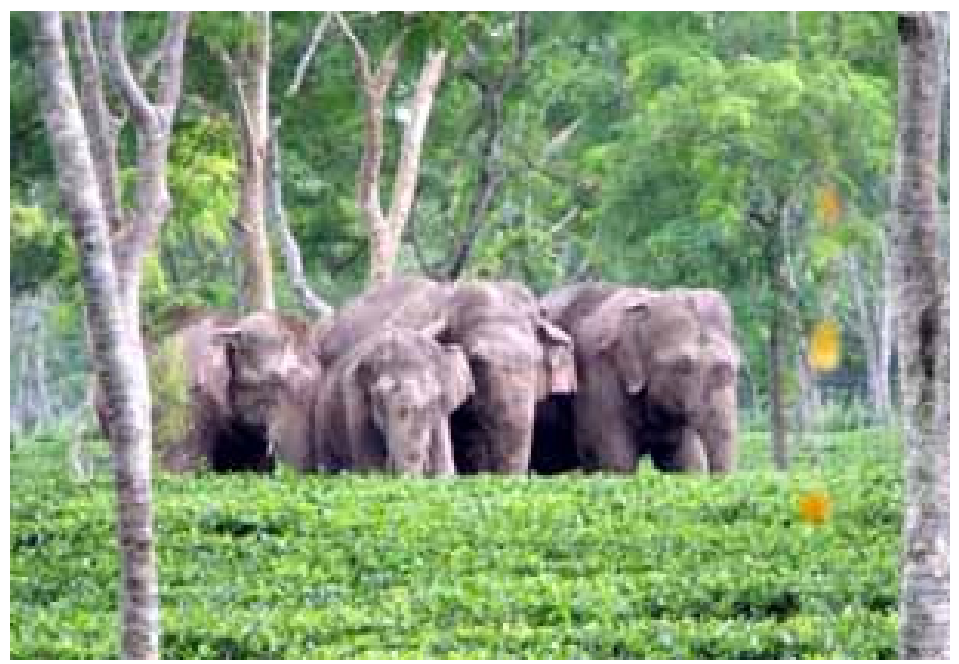

Figure 3: The SPo4 herd (left to right: Tara-4, Tara3, Tara-1 and Tara-5) in a tea plantation. Source: author.

Tracking the SPo4 herd was an event of feet following quadruped movement (Gooch, 2008). The elephants led us through different parts of the Sonitpur landscape, through places outside forest reserves left blank in the institutional rendering of this biogeography (Figure 1): the manicured slopes of the Phulbari tea estate where Tara-1 is standing up, alert, and guarding the herd whilst women pluck tea nearby; the deep ravines of Tarajuli where they are at ease, making us notice a place that would otherwise seem non-existent; the flat fields of Bokagaon where we hear them cross at night, the sounds of their quadruped movement interrupted by the pulse of road traffic. At times the herd is a set of traces - fresh footprints on red clay or signs of houses damaged. At other times, they are narratives - stories of people's encounters as they point to trampled fields. And then they are absences - we have no knowledge of their whereabouts. Only to resurface further north, amongst hordes of villagers using slingshots and beating metal tins to ward off the creatures. The places the herd prises open through translations are hybrid: partly Proboscidean, but not entirely human. Through this activity of tracking, we begin to perform a vital and relational topography, one through which I learn about the lay of the land. The AHP team's intimate knowledge of the landscape too had arisen from mapping SPo4's movements.

\footnotetext{
${ }^{4}$ The vernacular term mukhna, referring to tuskless adult bullsis widely used in the literature on Asian elephants.
} 
Following elephants, we also begin to animate the places I had encountered in archival documents. The herd moves through the Harchora Tea Estate, established in the 1860 s, with its long rows of 'labour colonies' housing communities brought to Assam as indentured labour (Behal and Mohapatra, 1992). We are on their tracks as they move into the Balipara Reserve, forests fenced off in the 1870 , where signs of erstwhile colonial forest plantations still remain (Saikia, 2005). They move into parts of the district we do not dare venture, as they are hideouts of secessionist rebels. These lapses mean that the herd's activities go undocumented. When they resurface, we follow the elephants toward Goroimari, a former elephant habitat requisitioned in 1950 to build an air base (Paramasivan, 1961). Through tracking, the pasts deposited in archives come to the fore, enabling one to write movement into inert texts and account for elephant presence in translations. The landscape becomes a palimpsest, replete with traces of past institutional arrangements and political struggles, muddied by quadruped soles and GPS points. Divisions between archive and field get blurred, as tracks oscillate from one to the other.

The AHP team had assembled a network of local informants, 'monitors', to relay information about elephant sightings, crop and house damage. We would then travel to these sites to find the herd, verify reports and plot coordinates of the location using a GPS device. This was a form of vernacular mapping, of reporting incidents that punctuated the rhythms of everyday rural life. The resultant cartography of everyday encounters (Figure 4), mapped through an assemblage that involved the SPo4 herd, local inhabitants, inscription devices such as mobile phones and GIS technologies, offers another way to articulate translations. The flurry of activity at the centre of this map diagrams SPo4's habit of resting in the relatively less populated tea plantations and scrubland during the day, forays into houses and paddy fields at night. A series of speculations on how elephants continually inhabit places outside the designated Sonitpur Elephant Reserve emerge. This vernacular unsettles Modernist cartographies, rendering visible SPo4's transgressions of reserve boundaries. Dhruba explains the map to me: "We might designate specific forest reserves for elephants, but this is very different from the ways in which the elephants think of their habitat. For all you know, elephants might consider human settlements and agriculture - 'our space' as theirs as well".

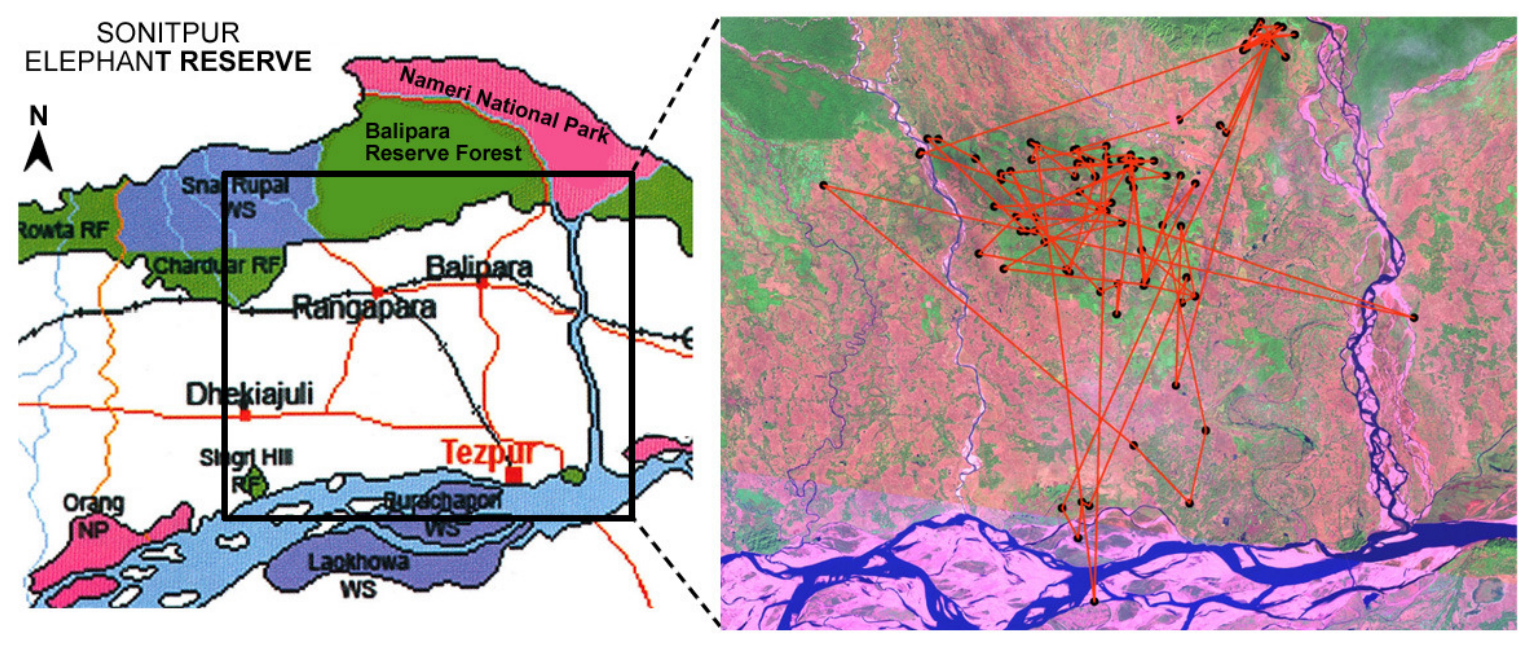


Figure 4: Map of $\mathrm{SPO}_{4}$ movements during the course of my fieldwork (right). Black points indicate reported sightings of the herd and red connectors are paths drawn between points. Green indicates tea estates, village home gardens or forest fragments; paddy fields are indicated by brown (Cartography: Scott Wilson / Assam Haathi Project). Inset on left shows area covered by this map, most of which falls outside the designated Elephant Reserve.

Cohabitation affected the herd's ethology. During the wet monsoon months the animals often ventured into paddy fields at night. In the fallow winter season, led by Tara-1, they would gravitate toward villages where grain was stored in people's homes. Ethologically, this manifested in highly developed raiding skills. The AHP database showed that the herd had broken fifty-five houses in the landscape over a one-year period in 2010. Dhruba suggested that there was always 'an element of surprise' in their raids: "This is why they are successful. ... They are very clever, and do not unnecessarily waste energy by breaking the entire house. Neither do they raid at unnecessary hours, for instance in the early evening when people are up and alert." Other herds in the vicinity are not equally skilled: "There are many elephants that act like crazy animals on a rampage and damage the entire house. Unlike SPo4, they are not calm." Ecologists suggest that crop-raiding is a learnt habit (Sukumar, 1996), certain individuals gaining greater propensity and skill in doing so (Srinivasaiah et al., 2012). Such skills may be passed down by older bulls to younger members of a herd. Over the years Dhruba noticed that Tara-3's skills had improved in Tara-1's presence.

Attending to these translations foregrounds the sentient ecologies of the SPo4 herd. Unlike archival readings, which only indicate how elephants resist human placings, this ecological rendition enables an engagement with the ways through which elephants create their own spaces, where their Proboscidean ways, ends, doings can be reflected. Foregrounding the lifeworlds of elephants, attending to their inhabitation of landscapes, reverses the Western, Modernist emphasis that building precedes dwelling (Heidegger, 2001; Ingold, 2011). Contrary to colonial cartographies of resource use, the earth's surface is not already laid out and fissured into distinct spaces for people and elephants. Rather, landscapes are a dwelt achievement. They emerge through the continual unfolding of the life activities of people and elephants, activities that issue forth through lines (Ingold, 2011). Or, to borrow my informants' terminology, landscapes are the interweaving of tracks. To view dwelling as an activity that occurs through lines or tracks has several meanings. First, it shifts understandings of landscapes as closed perimeters (which give rise to the dualisms of organism/environment, nature/society), to interweavings of 'trail[s] along which life is lived' (Ingold, 2008, p.1805). It is through these tracks of human feet and quadruped movement that nature and society knot to constitute all that is 'hybrid' about landscapes (Whatmore, 2002). Second, dwelling along tracks emphasizes the activities of elephants and people as place-binding rather than place-bound (Ingold, 2011). Thus, the lines on the map diagramming the back-and-forth journeys of the SPo4 herd are space-making activities constituted through human-elephant encounters, not transport between fixed locations or cartographic points (Gerlach, 2013; Ingold, 2011). Third, dwelling along tracks reorient views of landscapes from being surfaces of inscription to mediums of inhabitation. The resultant bio-geography, written by human and elephant bodies as they move through a lively earth, is 
an emergence rather than an inscription, where the 'creeping entanglements of life ... inevitably triumph over our attempts to box them in’ (Ingold, 2008, p.1809).

\section{Bio-geo-graphy III: Tracking stories}

Whilst the previous section shows how elephants dwell and co-fabricate landscapes, the voices of the rural poor are a telling absence. In this section, I seek to consider the experience of cohabitation from the perspective of the subalterns whose lives regularly interface with elephants. How are their lives, or tracks, caught up in fields of power? What bearings would an appreciation of people's stories have on our understanding of the politics of inhabiting landscapes? To answer these questions, I extend the method and metaphor of tracking to follow the stories of people as they interacted with the SPo4 herd.

During the course of my fieldwork in Sonitpur, I gained access to an AHP database of the houses the SPo4 herd had broken into in the past four years. This database provided an opportunity for further methodological innovation as it opened up avenues for 'reconstructing' past encounters between people and the herd. With the help of the AHP team, I travelled to these homes, strewn across different parts of the Sonitpur landscape. I conducted eighteen ethnographic interviews (Hammersley and Atkinson, 2007), through which I sought to evoke people's memories of the event and elicit stories about the herd in the context of the everyday. These interviews were conducted in informal settings, sometimes taking the form of spontaneous focus groups where several members of the household and occasionally neighbours joined in. I realize that there is a bias in selecting only those houses that were damaged, as it restricts analysis to events involving conflict; other views and ways of cohabiting with elephants may be downplayed. Similarly, focusing on one bull herd does not encapsulate encounters with other elephants whose behaviour and ecologies may be different. Hence, this attempt to story people's encounters should be read as a partial ethnographic perspective (Haraway, 1991), one that emerges through a specific set of interactions with a particular herd, rather than an exalted claim to speak about all modes of cohabitation.

Narratives of past encounters bring subaltern modes of cohabiting with elephants to life. One of the first people I interviewed was Putru, a twenty-eight year old tea plantation worker who lived with his wife and child in the Phulbari tea estate. The database recorded his house as one of 'thirteen huts damaged in the area'. Putru recounted the event with anguish: "The elephants came at night and broke into the room in which I was sleeping. Not finding any food, they went and demolished my neighbour's kitchen wall, then a couple of other houses, only to come back here again. I desperately tried to stop them. But they charge! They will trample you! It is all so sudden that there is no time to even light a fire. What will you do?" Residents of Sonitpur reiterated the AHP team's observation of how skilled the SPo4 herd had becoming in breaking into houses. Budhiram, an eighteen year old boy, described the elephants as "clever", approaching houses very silently at night: "The large one breaks in from the side, whilst the others wait at the front and back of the house... When people chase them, they hide. You think they have gone, but they come back again." Putru told me that these elephants "could not be trusted" as they could come any time of year and at unexpected hours: "Sometimes there are three, at other times two or four elephants ... The moment you open the door, they will strike. You tell me, how can one escape?" 
Stories about the herd circulated in the landscape, earning them the reputation of being 'raiders'. People like Putru readily distinguished $\mathrm{SP}_{4}$ from other elephant herds: "None of them have tusks... They roam around in our vicinity, going into villages and breaking houses. I was told by people that when you chase them, they retaliate. They were right." Andreas, another tea plantation worker who had his house broken into thrice, spoke of their fearless behaviour: "If you chase other crop-raiding elephants, they leave the fields, or even go away. But not these elephants ... They are obstinate. They only break houses". People had given the herd names. Bahadur, a sugarcane farmer, said they were the 'party of thieves', as they broke into houses. Debanand, a former mahout living in a different corner of the district, described Tara-1 as the "very tall elephant, the proud one who shows off". The latter's remarks reflected Tara-1's bodily stature and leadership of herding the other bulls. This description was not very different from those the AHP team used when talking about the animal's dispositions.

There was a belief that the herd's ethological dispositions had become different from other elephants due to inhabiting human landscapes: "Entering homes has become their habit ... they are so habituated that they won't even budge ... In fact, they have become like humans" (Putru). Some even said that the animals scaped their own places: "For instance, Hātidobā" in Phulbari tea estate. That is their space, a place where they congregate during the day." Cohabiting with elephants affected people's everyday activities. Bahadur had abandoned cultivating his sugarcane fields, as he was unable to guard them from elephants. Putru's travels were affected for he could not leave his family alone at night. He was seriously considering moving somewhere else with less elephant presence: "A home can be rebuilt. But what if someone is killed? Will you be able to bring back their lives?" The histories of state control and its fissured cartographies of elephants had bearings on how people's relations with elephants unfolded. Putru argued that elephants were forest department property. It was the latter's responsibility to prevent animals from foraying into villages: "Anything that is in the forests belongs to the government, the elephant being one of them. The government has employed foresters. They should prevent them from coming into our homes." Anger and frustration toward elephants were often directed toward the government. An interviewee whose house had been damaged by the SPo4 herd remarked: "This band of elephants that comes into our village is government dacoits! The government has kept these three to wreak havoc!" A frequent descriptor of the herd's activities was that they "carried out an eviction". Through the 1990s, the forest department had undertaken several eviction drives in Sonitpur (Gureja et al., 2002). Both the mobilization of the metaphor of eviction and allusion to elephants as 'government dacoits', reflect how Modernist legacies are inherited and schisms of purification and inversion are internalized by postcolonial subjects. Indeed, peoples' lives and the tracks of elephants get entangled with institutions of power. As the following vignette illustrates, dwelling with elephants may be a fraught process involving struggle and defeat for the poor. In September 2009, the SPo4 herd had broken twelve houses in the vicinity of Balipara. One such hut belonged to a family of landless labourers living at the periphery of a corporate-owned tea estate. Although the family of five fled unhurt, a burning kerosene lamp fell over as the elephants

\footnotetext{
${ }^{5}$ The term means 'elephant-pool' in Assamese.
} 
demolished a wall. The family's entire possessions were burnt down. Ironically, the only belonging they managed to retrieve were the few sacks of rice the elephants got hold of. Mala, the forty-year old woman to whom the house belonged, described their helplessness: "We watched our home burn with tears in our eyes. There were three elephants. Tell me, what could we do?"

The family became homeless. As temporary labourers they did not get any compensation or support from the corporate tea estate. For weeks they lived with neighbours in adjacent labour quarters. Mala described their poverty-stricken condition: "We couldn't even afford to buy a new set of clothes. We just wore what we had on that night." Her son Ramu, who worked as a truck driver, lost his driving license in the fire and consequently became unemployed. The episode deeply affected Ramu who, according to his family, 'became mad'. After numerous failed consultations with traditional healers, the family then took him to the local mental health services where he was diagnosed with an Acute Schizophrenia-like disorder. His condition improved after medication, but the family's problems did not. Ramu's father, who at the time worked as a daily labourer in a neighbouring state, returned home with some cash reserves. Due to his own poor health, the family persuaded him to stay back, further stifling their already-limited sources of income.

The subsequent trajectory of their lives, following the encounter with the herd, exposed the family to a range of institutional inequalities. To rebuild their home and pay for medical treatment, the family borrowed a sum of Rs. 2500 (US\$ 60) from a local moneylender at an interest rate of $10 \%$ a month. Families often put their land on mortgage to repay such debts. When I asked Mala why they had not applied for a government housing scheme for which the poor were eligible, she replied "We don't even have a 'BPL' [Below Poverty Line] card to show that we are poor. Who is going to make a card for us? When you go to the local office the first thing they do is ask for money." A similar story unfolded when they approached the forest department for compensation under the Project Elephant scheme. Being illiterate, local tea labour student union leaders filed a complaint on their behalf. A year had already passed without any signs of compensation. Repeated travels to the local forest office, at times sacrificing an entire day of paid work, were of no avail. When Mala approached the local student union leaders, she was told to "mind her own business". The helpless family suspected that someone else had collected compensation under their name.

The lines through which these stories and lives issue forth are inherently entangled in fields of power. The vignette of Mala and her family illustrates what tracking stories have to offer if one is to write about the fraught politics of cohabitation. The family's tracks moved through unequal terrain, intertwining with a host of other, often more powerful, actors: healers, the clinic, moneylenders, students unions, and the postcolonial state. In this specific instance, pre-existing poverty and inequality was aggravated through new entanglements formed after the elephant attack, not dissimilar to the impacts environmental calamities have on the rural poor. Tracking stories of the subalterns retrieves voices that may not make their way to archives or may get downplayed when there is an overt emphasis on nonhuman ecology. It brings to life some of the travails of the disenfranchised, the subjects of (post)colonial coercion and control, in the context of an everyday that is never outside a sticky web of connections with nonhumans. 


\section{Discussion: landscape, dwelling and political ecology}

This paper has brought the vitalist dispositions of more-than-human geography into conversation with strands of subaltern or postcolonial political ecology. The paper mobilizes conceptual resources from both discursive fields through a triad of methodological interventions examining the vital, political connections between the bio (human, elephants) and the geo (landscape). I have termed these interventions bio-geo-graphies to reflect the more-than-human nature of the project, articulated in conjunction with a retinue of nonhuman bodies, technologies and devices that interface with a lively earth. The 'dwelt political ecology' developed as a consequence makes a number of contributions to wider literatures in environmental history, political ecology and more-than-human geography. In this section I will briefly elucidate the main implications of this work and what it might offer for future scholarship.

First, the archival writing of human-elephant relationships speaks to literatures on South Asian environmental history (Arnold and Guha, 1995; Gadgil and Guha, 1992; Rangarajan, 1996a), and its concomitant subaltern political ecologies (Robbins, 2011). The critical examination of how histories of ordering human-elephant landscapes proceeded through Modernist processes of purification and inversion add a geographical sensibility to writings on environmental history (Gadgil and Guha, 1992; Rangarajan, 1999). Foregrounding the voices of the subaltern, and emphasizing the political economies of resource use, speaks to other histories of human-elephant relations centred on colonial figures and institutions (Lorimer and Whatmore, 2009; Sivasundaram, 2005). More critically, the emphasis on translations brings in new perspectives on writing (post)colonial histories from the archives. Whilst subaltern studies historians have read archives against the grain of colonial and nationalist histories of India (Chakrabarty, 2002; Guha, 1982; Simeon, 2001), nonhumans and their agentic potential eludes critical enquiry. Histories of Indian environmentalism too seem to tidy up the actions and lifeworlds of the animals that populate their accounts (Gadgil and Guha, 1992; Rangarajan, 1996a, 2006). By foregrounding translations, this paper shows how in certain places, subaltern pasts and political struggles are shaped with and through elephants, or for that matter by a retinue of nonhuman beings with which human lives are led.

Further, the paper opens up some difficult questions that strike at the heart of postcolonial environmental history. One such concern is whether attending to the lifeworlds of elephants is a manoeuvre to examine histories against the anthropocentric grain of subaltern studies? There are indeed many subalterns, human and nonhuman, and even many more ways to be subalterns who cannot speak. Writing about nonhuman others is a difficult endeavour (Hinchliffe et al., 2005), a concern that is shared by subaltern studies scholars (Spivak, 1988). It is perhaps not a question of pitting posthumanist concerns against the postcolonial, a trap that some posthumanists seem to have fallen into (Wolfe, 2003), but about a critical engagement that does not edit out both marginal voices and the nonhuman world. Cohabitation can be a fraught endeavour for both humans and elephants as they dwell in landscapes riven with conflict. More-than-human geography has a privileged vantage point to address concerns of how history and social life are always in excess of the human (Castree et al., 2004). A further dialogue with postcolonial studies is likely to be an arena for much productive future scholarship. 
Leading on from this, the second important contribution of this paper has been to vitalize political ecology. It takes as its point of departure two criticisms that have been levelled against the discipline. Firstly, the lifeworlds of animals are rendered inert such that they hardly appear in political ecology as anything more than animated cultural constructs (Hobson, 2007). Secondly, the landscape becomes a tabula rasa upon which contending knowledge claims are inscribed (Hinchliffe, 2003). Consequently, the material connections between human and animal bodies and a lively earth are reduced to a political remainder in most accounts. Scholars are now beginning to pay closer attention to the liveliness of animals, particularly in relation to different knowledges about animals (Goldman, 2007; Nadasdy, 2007), and their role as participants in environmental politics (Dempsey, 2010). Building upon this nascent literature, this paper offers up a 'dwelt political ecology' where elephants are qualitatively present and landscapes are understood as enfoldments emerging through the activities of humans and elephants. The 'dwelling perspective' deployed works against the grain of inversion that delineates animals and landscapes as bound objects contained within a perimeter. Dwelling is a concept drawn from the work of Ingold and his reading of Heidegger's famous essay Building, Dwelling, Thinking (Heidegger, 2001; Ingold, 2000, 2011). Following Ingold, this paper shows how both elephants and humans are open to the creative traffic of the world. As sentient agents, the SPo4 herd scapes spaces in conjunction with humans. They apprehend them in their own speeds, rhythms and distances. The elephants' prolonged inhabitation in the 'here' of society affects their ethologies. Skills in negotiating human presence, learning to break into houses and raid crops with ease, stand out as markers. Similarly, people's lives get attuned to the movements and activities of elephants, sometimes even a sort of calibration as they stay up to guard crops or stand vigil. This dwelt geography ecologizes human-animal relations, where landscapes are a process unfolding through those very relations.

The contribution this paper makes to scholarship on dwelt geographies of animals (Johnston, 2008; Lorimer, 2006), has been to attend to the politics that emerges when dwelling rubs against institutional orderings and landscape design. Couched in its brand of Heideggerian romanticism, dwelling risks 'conjuring up a haven of rest where all tensions are resolved, and where the solitary inhabitant can be at peace with the world - and with him or herself (Ingold, 2005, p.503). In contrast, this paper argues that human and animal lives are lived collectively within fields of power, and analyses some of the (post)colonial histories through which they proceed. For instance, cohabiting with the $\mathrm{SPo} 4$ herd is preceded by a legacy of state ownership and commodification of the elephant. The latter is not a marginalized other, but a creature that has benefited from over a century of state protection and deployed to legitimize control over resources and land. The struggles, failures and defeat in the face of state power manifests in metaphors of elephants being 'government dacoits' or 'animals carrying out evictions'. Elephants in fact may operate as vectors that aggravate pre-existing poverty or expose the poor to new spaces of inequality. The travails of Mala's family, as they encounter government departments, local politicians and moneylenders following the elephant attack, speak back to Heidegger and his romantic notion of dwelling.

Conflicts between people and wildlife have received sustained attention from studies mobilized through the imperatives of conservation (Barua et al., 2010; Redpath 
et al., 2013; Woodroffe et al., 2005). Such work examines the drivers of conflict and emphasizes how they could be mitigated. However, they have a tendency to evoke people's relations with wildlife through a Western axis of calibration, whereby cultural ambivalences and complexities get written off (Goldman et al., 2010; Goldman et al., 2011). The specificities of this ethnography does tilt toward conflicting encounters, but a number of ambiguities open up the multi-faceted nature of cohabitation. First, notions of vilifying the SPo4 herd as 'dacoits' rested closely with observations of the animals being 'clever', an appreciation of elephants' intelligence and skills to cope with the demands of inhabiting human habitation. Similarly, elephants were associated with the Hindu deity Ganeśa, a mark of respect which, in combination with state protection afforded to the species, operates to stall lethal retribution against elephants. Reverence in fact has been a force that led to political opposition toward suggestions of culling elephant populations in Assam in the past (Stracey, 1963). Despite the burdens of cohabitation, none of the respondents said that elephants should be eliminated. Second, people drew differences between the SPo4 herd and 'other elephants' that retreated when chased. This ethnography thus highlights the importance of elephant difference: not all animals are alike, for they have different ethologies and personalities that influence ways in which cohabitation is perceived and performed. Such specificity complicates conservation narratives that have a tendency to posit cultural reverence toward elephants in India in trans-historical and trans-contextual terms (Gureja et al., 2002). Third, the notion that elephants were animals 'belonging to forests' rubbed up against other interpretations that landscapes were shared spaces. Cartographic schisms, whilst internalized by certain subjects, are also ridden with ambiguities.

Engaging with translations, and writing about the politics that emerges through the connections woven between the bio and the geo, demands methodological innovation that does not sit easily with the orthodox approaches of the interpretative social sciences. The third, and significant, contribution of this paper has been to devise and deploy a method that enables articulations of history, politics and ecology in a way that does not tidy up the lifeworlds of nonhumans or silence the voices of the marginalized. This methodology cobbles together a variety of practices and sources: tracing material in online and institutional archives, tracking elephants and walking a sentient topography, consulting repositories of past local events and opening up political ecologies through people's stories. Borrowing my field informants' terminology, I have termed this endeavour of shuttling between field and archive, ecology and story, as 'tracking'. Tracks are the lines of movement or becoming through which human and nonhuman life flow (Deleuze and Guattari, 1987; Ingold, 2011). They open up a world of becoming and movement in which the lives of people and animals, at any place or moment, enfold within histories, ecologies and stories of relations that have brought them there. To read into archives, to be surrounded by the voices of pages, is akin to a hunter surrounded by voices of the land -a labour of following the traditions animals are entwined in (Ingold, 2013). The term tradition comes from 'trade', which originally meant 'track'. Archival research could thus be seen an activity of tracking histories of these creatures, their relations with people and institutions, as though one were a hunter back through time (Sax, 2001).

The same holds for writing political ecologies in the present; as a method, tracking elephants means attending to the creatures' ethologies, to their sentient 
lifeworlds as they interface with people, institutions and management regimes. It resists interpretations of landscapes being surfaces of inscription. Rather, the entwining of these ever-extending tracks weave together a texture that one terms landscape: partly Proboscidean, partly human, never sealed or bound by a perimeter. Stories too are a form of knowledge that issue forth along the tracks of people as they make their way from place to place, encounter a host of actors, human and nonhuman (Ingold, 2011). Ethnographic research is about tracing such stories, to track how they are bound up with institutions of power, political struggles or historical events. Tracking is both metaphorical and a practical, sensuous activity; by weaving different tracks together we begin to articulate a political ecology of dwelling. A subaltern reading is to bring these tracks closer to the ground, to the struggles and the defeats of quadruped soles and bare feet.

These methods chime with some of the experimental and innovative approaches of more-than-human geography and nonrepresentational theory. For instance, scholars writing about the histories of animals and their landscapes have begun to complicate and problematize distinctions between sites demarcated as 'archive' and 'field', and therefore between past history and present ecology (Lorimer, 2006). The collagist and chthonic character of such 'make-do' methods (Lorimer, 2009), is deployed in this work but with a more implicit effort to listen to 'small stories' and write them 'from below', to tune into colonial pasts and postcolonial presents. Relational political ecologies that interrogate the primacy of scientific understandings of animal biogeographies by counterpoising them with indigenous interpretations (Goldman, 2007), or by foregrounding non-Western ontologies (Nadasdy, 2007), similarly give a political edge to human-animal relations. This paper enhances these approaches by offering up a methodology that renders visible the material lives and spaces of animals, how the latter too participate in processes of knowledge production. The distinctive contribution of this paper is that it posits a way in which conceptual and methodological resources offered up by both more-thanhuman geography and political ecology can be harnessed productively, through its particular brand of calibrating ethology and ethnography, ecology and politics.

The politics of human-elephant cohabitation elucidated here has implications for the emerging work of human geographers interested in the dynamics and distribution of life in the Anthropocene (Lorimer, 2012). Attempts to craft intradisciplinary or 'lively' biogeographies of Asian elephants have opened up new ways through which we might think about human-elephant relations (Lorimer, 2010b). This work proposes ways in which the concerns of diverse epistemic communities, sentient organisms and discordant rhythms of dynamic landscapes can be written into biogeographies of Asian elephants, a domain that has traditionally been the forte of the ecological sciences. Concerned with large spatial scales and mapping humans into biogeographic units and macro-ecological processes, this work harks back to some of the zoogeographic roots of animal and cultural geography (Lorimer and Srinivasan, 2013; Philo, 1998), albeit with a much more sophisticated understanding of culture and nonhuman agency. This paper extends such efforts by showing how landscape-scale conservation biogeography is a product of specific historical trajectories, involves multiple modes of human-elephant cohabitation, and are characterized by different elephant cultures. Here, methodological interventions through archival and ecological work resist reifying biogeographic units, instead highlighting the practices 
and politics through which they are constructed and mapped. Similarly, it restores into the analysis lived experiences of inhabitation which weave the bio and the geo together. Whilst attending to a very specific sentient ecology of an elephant herd and their becomings in a landscape with depleted resources, the paper highlights different modes of being that get subsumed under the appellative 'elephant'. It shows how distinct 'elephant cultures' that emerge through particular ecologies of relations matter (Bradshaw, 2009). Here, one might ask whether, in the face of increasing deforestation and conflict across elephant ranges in Asia, elephants of the Anthropocene would become like the SPo4 herd. Attending to the new biogeographies emerging as humans become a life-altering force on the planet is an arena of scholarship waiting to explode.

By renewing connections between the bio and the geo in a context where the modality of life is politically molten, a common ground between more-than-human geography and political ecology emerges. This paper has shown how the apparent 'tensions' between these theoretical stances can indeed be used productively (Neumann, 2011). The dwelt political ecology developed here draws from both the vitalist dispositions of more-than-human and non-representational approaches as well as the (post)colonial critiques of political ecology. It has sought to go beyond the humanist frameworks of political ecology, whilst retaining its analytical purchase for understanding human-animal relations as they unfold over asymmetric terrains. This paper opens up some new avenues for future research, avenues one hopes other geographers will track. 


\section{References}

Agrawal A, 2005 Environmentality: Technologies of Government and the Making of Subjects (Duke University Press, Durham, NC)

Anon., 1957, "Progress Report of Forest Administration in the State of Assam for the year 1949-50.", (Assam Government Press, Shillong)

Arnold D, Guha R, 1995 Nature, Culture, Imperialism: Essays on the Environmental History of South Asia (Oxford University Press, New Delhi)

Barua M, Tamuly J, Ahmed R A, 2010, "Mutiny or Clear Sailing? Examining the Role of the Asian Elephant as a Flagship Species." Human Dimensions of Wildlife 15 145160

Behal R P, Mohapatra P, 1992, "'Tea and money versus human life': The rise and fall of the indenture system in the Assam tea plantations 1840-1908" Journal of Peasant Studies 19 142-172

Bist S S, 2006, "Elephant conservation in India - an overview." Gajah 25 27-35

Bradshaw G A, 2009 Elephants on the edge: what animals teach us about humanity. (Yale University Press, New Haven)

Campbell A, 1869, "Notes on the mode of Capture of Elephants in Assam" Proceedings of the Zoological Society of London 37 136-140

Castree N, Nash C, Badmington N, Braun B, Murdoch J, Whatmore S, 2004, "Mapping posthumanism: an exchange" Environment and Planning A 36 1341-1363

Chakrabarty D, 2002 Habitations of Modernity: Essays in the Wake of Subaltern Studies (University of Chicago Press, Chicago)

Deleuze G, Guattari F, 1987 A Thousand Plateaus: Capitalism and Schizophrenia (University of Minnesota Press, Minneapolis, MN)

Dempsey J, 2010, "Tracking grizzly bears in British Columbia's environmental politics." Environment and Planning A 42 1138-1156

Fairhead J, Leach M, 1996 Misreading the African landscape: society and ecology in a forest-savanna mosaic (Cambridge University Press, Cambridge)

Gadgil M, Guha R, 1992 This Fissured Land: An Ecological History of India (Oxford University Press, New Delhi)

Gee E P, 1950, "Wild Elephants in Assam" Oryx 1 16-22

Gerlach J, 2013, "Lines, contours and legends: Coordinates for vernacular mapping" Progress in Human Geography DOI: 10.1177/0309132513490594

Goldman M, 2007, "Tracking wildebeest, locating knowledge: Maasai and conservation biology understandings of wildebeest behavior in Northern Tanzania" Environment and Planning D: Society and Space 25 307-331

Goldman M J, De Pinho J R, Perry J, 2010, "Maintaining Complex Relations with Large Cats: Maasai and Lions in Kenya and Tanzania" Human Dimensions of Wildlfe $15332-346$

Goldman M J, Nadasdy P, Turner M D, 2011 Knowing Nature: Conversations at the Intersection of Political Ecology and Science Studies (University of Chicago Press, Chicago)

Gooch P, 2008, "Feet Following Hooves.", in Ways of Walking: Ethnography and Practice on Foot Eds T Ingold, J L Vergunst (Ashgate, Farnham, Surrey) pp 6780

Gramsci A, 1971 Selections from the Prison Notebooks of Antonio Gramsci (International Publishers, New York) 
Guha R, 1982, "On Some Aspects of the Historiography of Colonial India" Subaltern Studies 1 1-19

Guha R, 1990 The unquiet woods: ecological change and peasant resistance in the Himalaya (University of California Press, Berkeley)

Gureja N, Menon V, Sarkar P, Kyarong S S, 2002, "Ganesha to Bin Laden: Humanelephant conflict in Sonitpur District of Assam.", (Wildlife Trust of India, New Delhi) p 45

Hammersley M, Atkinson P, 2007 Ethnography: Principles in Practice. (Routledge, London)

Handique R, 2004 British Forest Policy in Assam. (Concept Publishing Company, New Delhi)

Haraway D, 1991 Simians, Cyborgs, and Women: The Reinvention of Nature. (Free Association Books, London)

Heidegger M, 2001 Poetry, Language, Thought (HarperCollins, New York)

Hinchliffe S, 2003, "Inhabiting: landscapes and natures.", in The Handbook of Cultural Geography Eds K Anderson, M Domosh, S Pile, N Thrift (Sage, London)

Hinchliffe S, Kearnes M B, Degen M, Whatmore S, 2005, "Urban wild things: a cosmopolitical experiment." Environment and Planning D: Society and Space 23 $643-658$

Hobson K, 2007, "Political animals? On animals as subjects in an enlarged political geography." Political Geography 26 250-267

Hunter W W, 1879 A Statistical Account of Assam (Trubner \& Co., London)

Ingold T, 2000 The Perception of the Environment: Essays on livelihood, dwelling and skill. (Routledge, London)

Ingold T, 2005, "Epilogue: Towards a Politics of Dwelling." Conservation and Society 3 501-508

Ingold T, 2008, "Bindings against boundaries: entanglements of life in an open world" Environment and Planning A 40 1796-1810

Ingold T, 2011 Being Alive: Essays on Movement, Knowledge and Description. (Routledge, Abingdon, Oxon)

Ingold T, 2013, "Walking with Dragons: An Anthropological Excursion on the Wild Side", in Animals as Religious Subjects: Transdisciplinary Perspectives Eds C Deane-Drummond, R Artinian-Kaiser, D L Clough (Bloomsbury T\&T Clark, London) pp 35-58

Jepson P, Barua M, Ladle R J, Buckingham K, 2010, "Towards an intradisciplinary biogeography: a response to Lorimer's 'lively biogeographies' of Asian elephant conservation." Transactions of the Institute of British Geographers 36 170-174

Johnston C, 2008, "Beyond the clearing: towards a dwelt animal geography." Progress in Human Geography 32 633-649

Lahiri-Choudhury D K, 1989, "The Indian Elephant in a Changing World", in Contemporary Indian Tradition: Voices on Culture, Nature, and the Challenge of Change Ed C M Bordeon (Smithsonian Institution Press, Washington D.C.) pp 301-321

Lahiri-Choudhury D K, 2006 A Trunk Full of Tales: Seventy Years with the Indian Elephant (Permanent Black, New Delhi)

Latour B, 1993 We have never been modern. (Harvard University Press, Cambridge, MA) 
Law J, 1999, "After ANT: complexity, naming and topology", in Actor Network Theory and After Eds J Law, J Hassard (Blackwell Publishing, Oxford) pp 1-14

Lestel D, Brunois F, Gaunet F, 2006, "Etho-ethnology and ethno-ethology" Social Science Information 45 155-177

Lorimer H, 2006, "Herding memories of humans and animals." Environment and Planning D: Society and Space 24 497-518

Lorimer H, 2009, "Caught in the nick of time: Archives and fieldwork", in The Handbook of Qualitative Methods in Human Geography Eds M Crang, D Delyser, S Herbert, L McDowell (SAGE, London) pp 248-273

Lorimer H, 2010a, "Forces of nature, forms of life: calibrating ethology and phenomenology", in Taking Place: Non-representational Theories and Geography Eds B Anderson, P Harrison (Ashgte, Farnham, Surrey) pp 55-78

Lorimer J, 2010b, "Elephants as companion species: the lively biogeographies of Asian elephant conservation in Sri Lanka." Transactions of the Institute of British Geographers 35 491-506

Lorimer J, 2012, "Multinatural geographies for the Anthropocene" Progress in Human Geography 36 593-612

Lorimer J, Srinivasan K, 2013, "Animal Geographies", in The Wiley-Blackwell Companion to Cultural Geography Eds N C Johnson, R H Schein, J Winders (Wiley-Blackwell, Oxford) pp 332-342

Lorimer J, Whatmore S, 2009, "After the 'king of beasts': Samuel Baker and the embodied historical geographies of elephant hunting in mid-nineteenthcentury Ceylon." Journal of Historical Geography 35 668-689

M'Cosh J, 1837 Topography of Assam (G. H. Huttmann, Bengal Military Orphan Press, Calcutta)

Nadasdy P, 2007, "The gift in the animal: The ontology of hunting and human-animal sociality" American Ethnologist 34 25-43

Neumann R P, 2011, "Political ecology III: Theorizing landscape" Progress in Human Geography $35843-850$

Nongbri N, 2003, "Elephant Hunting in Late 19th Century Northeast India: Mechanisms of Control, Contestation and Local Reactions." Economic and Political Weekly July 26 3189-3199

Ogra M V, 2008, "Human-wildlife conflict and gender in protected area borderlands: A case study of costs, perceptions, and vulnerabilities from Uttarakhand (Uttaranchal), India" Geoforum 39 1408-1422

Paramasivan R S, 1961, "Progress Report of Forest Administration in the State of Assam for the year 1950-51.", (Assam Government Press, Shillong)

Peluso N L, 1995, "Whose woods are these? Counter-mapping forest territories in Kalimantan, Indonesia." Antipode 27 383-406

Philo C, 1998, "Animals, Geography and the City: Notes on Inclusions and Exclusions", in Animal Geographies: Place, Politics, and Identity in the Nature-Culture Borderlands Eds J Wolch, J Emel (Verso, London)

Rangarajan M, 1996a, "Environmental histories of South Asia: a review essay" Environment and History 2 129-143

Rangarajan M, 1996b, "The Politics of Ecology: The Debate on Wildlife and People in India, 1970-95" Economic and Political Weekly 31 2391-2409 
Rangarajan M, 1999 Fencing the forest: conservation and ecological change in India's central provinces 1860-1914 (Oxford University Press, New Delhi)

Rangarajan M, 2006 India's wildlife history: An introduction (Orient Blackswan, New Delhi)

Redpath S M, Young J, Evely A, Adams W M, Sutherland W J, Whitehouse A, Amar A, Lambert R A, Linnell J D C, Watt A, Gutierrez R J, 2013, "Understanding and managing conservation conflicts" Trends in Ecology E Evolution 28 100-109

Robbins P, 2001, "Tracking Invasive Land Covers in India, or Why Our Landscapes Have Never Been Modern" Annals of the Association of American Geographers $91637-659$

Robbins P, 2011 Political ecology: A critical introduction (Wiley-Blackwell, Oxford)

Saikia A, 2005 Jungles, Reserves, Wildlife (Wildlife Areas Development and Welfare Trust, Guwahati)

Saikia A, 2008, "Forest Land and Peasant Struggles in Assam, 2002-2007." The Journal of Peasant Studies 35 39-59.

Sax B, 2001 The mythical zoo: an encyclopedia of animals in world myth, legend and literature (ABC-CLIO, Santa Barbara, California)

Simeon D, 2001, "Subaltern studies: Cultural concerns", in International Encyclopedia of the Social and Behavioral Sciences (London) pp 15241-15245

Sivasundaram S, 2005, "Trading knowledge: the East India Company's elepants in Indian and Britain." The Historical Journal 48 27-63

Spivak G C, 1988, "Can the subaltern speak?", in Marxism and the Interpretation of Culture Eds C Nelson, L Grossberg (University of Illinois Press, Chicago)

Srinivasaiah N M, Anand V D, Vaidyanathan S, Sinha A, 2012, "Unusual Populations, Unusual Individuals: Insights into the Behavior and Management of Asian Elephants in Fragmented Landscapes" PLoS ONE 7 e42571 42571-42516

Stracey P D, 1963 Elephant Gold (Weidenfeld and Nicolson, London)

Sukumar R, 1996 Elephant days and nights. (Oxford University Press, New Delhi)

Talukdar B N, 2010 Elephants in Assam. (Forest Department of Assam, Government of India., Guwahati)

Walker P A, 2005, "Political ecology: where is the ecology?" Progress in Human Geography 29 73-82

Whatmore S, 2002 Hybrid geographies: natures, cultures, spaces. (Sage, London)

Whatmore S, 2006, "Materialist returns: practising cultural geography in and for a more-than-human world." Cultural Geographies 13 600-609

Wolfe C, 2003 Animal Rites: American Culture, the Discourse of Species, and Posthumanist Theory (University of Chicago Press, Chicago)

Woodroffe R, Thirgood S, Rabinowitz A, 2005 People and Wildlife: Conflict or Coexistence? (Cambridge University Press, Cambridge)

Zimmerer K S, 1999, "Overlapping Patchworks of Mountain Agriculture in Peru and Bolivia: Toward a Regional-Global Landscape Model" Human Ecology 27 135-165

Zimmerer K S, Bassett T J, 2003 Political ecology: an integrative approach to geography and environment-development studies. (The Guilford Press, New York) 